University of Nebraska - Lincoln

DigitalCommons@University of Nebraska - Lincoln

Faculty Papers and Publications in Animal

Science

Animal Science Department

1997

\title{
Effects of Sire, Dam Traits, Calf Traits, and Environment on Dystocia and Subsequent Reproduction of Two-Year-Old Heifers
}

D. J. Colburn

University of Nebraska-Lincoln

Gene H. Deutscher

University of Nebraska-Lincoln, gdeutscher@inebraska.com

Merlyn K. Nielsen

University of Nebraska-Lincoln, mnielsen1@unl.edu

Don C. Adams

University of Nebraska-Lincoln, dadams1@unl.edu

Follow this and additional works at: https://digitalcommons.unl.edu/animalscifacpub

Part of the Animal Sciences Commons

Colburn, D. J.; Deutscher, Gene H.; Nielsen, Merlyn K.; and Adams, Don C., "Effects of Sire, Dam Traits, Calf Traits, and Environment on Dystocia and Subsequent Reproduction of Two-Year-Old Heifers" (1997).

Faculty Papers and Publications in Animal Science. 503.

https://digitalcommons.unl.edu/animalscifacpub/503

This Article is brought to you for free and open access by the Animal Science Department at DigitalCommons@University of Nebraska - Lincoln. It has been accepted for inclusion in Faculty Papers and Publications in Animal Science by an authorized administrator of DigitalCommons@University of Nebraska - Lincoln. 


\title{
Effects of Sire, Dam Traits, Calf Traits, and Environment on Dystocia and Subsequent Reproduction of Two-Year-Old Heifers ${ }^{1,2}$
}

\author{
D. J. Colburn, G. H. Deutscher3, M. K. Nielsen4, and D. C. Adams \\ West Central Research and Extension Center, University of Nebraska, North Platte 69101
}

\begin{abstract}
A study was conducted over $3 \mathrm{yr}$ to evaluate effects of sire birth weight EPD, calf birth weight and shape, and heifer pelvic area and weight, individually and in combination, on dystocia and subsequent rebreeding of 2-yr-old heifers. Heifers ( $\mathrm{n}=$ 550), MARC II yearlings, were assigned for breeding to one of four Angus sires with birth weight EPD of $-.95,-.82,+2.9$, and $+2.7 \mathrm{~kg}$. At calving, heifers were assisted as needed. A gauge attached to the calf puller recorded applied traction pressure. Analysis of traction pressure detected only slightly larger amounts of variation ( 2 to $3 \%$ ) affecting dystocia than the standard five-point scoring system. Dam weight did not affect calving difficulty score (CDS), except dam birth weights were heavier $(P<.05)$ for CDS 5 (Caesarean section) than CDS 1 (unassisted). Dams requiring Caesarean section had smaller pelvic areas
\end{abstract}

$(\mathrm{P}<.05)$, with no other differences among CDS. The CDS increased as calf birth weight and calf external measurements increased. Low EPD sires produced calves with smaller $(P<.05)$ birth weights and smaller calf head and foot circumferences and caused less dystocia than high EPD sires. The CDS did not affect subsequent pregnancy rates but did affect conception date of the second calf. Calves delivered by Caesarean section were lighter $(P<.05)$ at weaning than other calves but had similar slaughter weights. As mean winter temperature increased $\left(6.1^{\circ} \mathrm{C}\right)$ from yr 1 to 3, calf birth weight decreased $(4.6 \mathrm{~kg})$ and calving difficulty decreased $23 \%$. Results indicate sire birth weight EPD, calf birth weight and shape, dam pelvic area, and climate affected CDS, and CDS affected subsequent conception date.

Key Words: Dystocia, Heifers, Calf Measurements, Sire Evaluation, Pelvis

\section{Introduction}

Dystocia is one of the most important production problems of the beef industry and has been recognized as a major cause of early calf mortality (Laster et al., 1973; Smith et al., 1976; Patterson et al., 1979). Calving difficulty is costly to producers due to calf losses (Wiltbank et al., 1961) and decreased subsequent reproductive performance of cows (Brinks et al., 1973; Laster et al., 1973).

Literature reviews have reported the major cause of dystocia in 2-yr-old heifers was a disproportion between calf birth weight and dam's pelvic area (Deutscher, 1989; Anderson et al., 1993). Other

${ }_{1}$ ournal paper no. 11625 of the Agric. Res. Div., Univ. of Neb., Lincoln 68583-0704.

${ }^{2}$ Appreciation is expressed to ABS Global, Inc., DeF orest, WI, for partial funding of study.

${ }^{3}$ To whom correspondence should be addressed: Rt. 4, Box 46A, North Platte, NE 69101.

${ }^{4}$ Anim. Sci. Dept., Univ. of Nebraska, Lincoln 68583-0908.

Received August 20, 1996.

Accepted February 11, 1997. factors were calf sex, calf shape, sire, dam weight and condition plus environmental effects. Most research has investigated individual factors, not the total complex. Also, limited research has been published on climatic effects.

This study evaluated effects of multiple factors, including service sire birth weight EPD, calf birth weight, shape and various heifer measurements, individually and in combination, on dystocia and subsequent rebreeding of 2-yr-old heifers. The study also evaluated two methods of measuring dystocia: 1 ) kilograms of traction pressure and 2) the standard five-point subjective scoring system. In addition, climatic effects on dystocia and effects of dystocia on calf growth from birth to slaughter were investigated.

\section{Materials and Methods}

The study was conducted over 3 yr using 550 MARC II heifers ( $1 / 4$ Angus $\times 1 / 4$ Her eford $\times 1 / 4$ Simmental $\times$ $1 / 4$ Gelbveih). Heifer calves were born in March and April and grazed with their dams during the summer on native range at the Gudmundsen Sandhills Laboratory (GSL), Whitman, Nebraska. After weaning in 
early October, heifers remained at GSL grazing meadow regrowth. Beginning in December, heifers were fed hay and protein supplement. In March, the heifers were transported to the West Central Research and Extension Center (WCREC) in North Platte, Nebraska. Upon arrival, the heifers were placed in drylot and fed ground alfalfa hay, corn silage, and dry rolled corn. Heifers were fed to gain .59 to $.68 \mathrm{~kg} / \mathrm{d}$ to reach a target weight of $296 \mathrm{~kg}$ before the breeding season.

The same heifer allotment procedure was used each year beginning in April, when the heifers were weighed and their pelvic dimensions measured. To ensure assignment of service sires across all sizes of heifers, the heifers were assigned to 23-kg groups by weight, ranked on pelvic area from smallest to largest within these groups, and then allotted randomly to one of four Angus sires (American Breeders Service, ABS, DeForrest, WI). Two low and two high EPD sires for birth weight were used $(-.95,-.82,+2.9$, and $+2.7 \mathrm{~kg}$, respectively). All sires had accuracies greater than .95 for birth weight EPD when the study was initiated.

Body size traits were measured when the heifers were 12 (yearling), 18 (pregnancy check), and $22 \mathrm{mo}$ (precalving) of age. Body size measurements were weight, condition score, hip height, and internal pelvic dimensions (width, height, and area). Hip height was not measured at $18 \mathrm{mo}$. Pelvic measurements were taken by the same experienced investigator each year using a Krautman Bovine Pelvic Meter ( orgensen Laboratories, Loveland, CO). Pelvic height was the vertical distance between the sacral vertebrae and pubic symphysis; and pelvic width was the horizontal distance between the shafts of the ilium at the widest point. Pelvic area was the product of height times width. Visual body condition scores were assigned by the same technician each year on a scale of 1 to 9 , where 1 =emaciated; 5 =moderate; and $9=$ extremely fat.

The breeding season began May 10 each year and lasted for $42 \mathrm{~d}$. Heifers remained in drylot and were observed twice daily for standing estrus. Approximately $12 \mathrm{~h}$ after standing estrus, heifers were artificially inseminated with semen from the assigned sire. When a heifer returned to estrus during the breeding season, she was inseminated again with semen from the same sire. The same four sires were used each year. Four technicians inseminated the heifers with each artificially servicing approximately the same number of heifers per sire. After the breeding season, heifers were moved to native range.

Pregnancy examinations were performed via rectum $60 \mathrm{~d}$ after the end of the breeding season. Nonpregnant heifers were removed from the study. Pregnant heifers remained on pasture and were fed supplemental protein during the fall. In January, pregnant heifers were given ad libitum access to brome hay (average $10 \% \mathrm{CP}$ ) at $9.1 \mathrm{~kg} / \mathrm{d}$ and alfalfa hay (average $17 \%$ CP) at $1.8 \mathrm{~kg} / \mathrm{d}$. Approximately 10 d prior to predicted calving date, individual heifers were moved to the calving lot where they received the same diet as previously fed.

During the calving season, which began in early F ebruary, the heifers were checked every $2 \mathrm{~h}$ for signs of parturition. Once the amniotic sac appeared, heifers were checked every $30 \mathrm{~min}$ for progress and any possible complications. If adequate progress had not been made by 90 min after the amniotic sac appeared, the heifer was assisted in parturition. A traction pressure gauge was attached to the calf puller (Daryl Strohbehn, I owa State University, personal communication) to determine the maximum kilograms of pressure required to deliver the calves requiring assistance. Heifers were first scored on a scale of 1 to 5 on the degree of dystocia, where $1=$ no assistance, $2=$ easy pull, $3=$ mechanical pull, $4=$ hard mechanical pull, and $5=$ Caesarean section. After the calving difficulty score (CDS) was determined, the pressure reading was then recorded.

When calves could not be delivered with a puller and were taken by Caesarean section, a single pressure value was assigned that was greater than the maximum of CDS 4 values. The pressures for each CDS were 33 to $56 \mathrm{~kg}, 57$ to $281 \mathrm{~kg}, 282$ to $364 \mathrm{~kg}$, and $386 \mathrm{~kg}$ for CDS 2, 3, 4, and 5, respectively. Data from heifers with abnormal presentations and twins were deleted from the analyses.

Calving traits recorded immediately after parturition included calf sex, calving date, calving difficulty score, and delivery pressure. All calves that were assisted at birth were orally drenched with at least $500 \mathrm{~mL}$ of colostrum from their dam. Calf vigor scores were recorded on the scale of 1 to 5 , where $1=$ nursed unassisted within $30 \mathrm{~min}, 2=$ nursed unassisted within 30 to $60 \mathrm{~min}, 3=$ nursed unassisted within 60 to $75 \mathrm{~min}, 4=$ didn't nurse within $75 \mathrm{~min}$ and was assisted, and $5=$ dead at birth. Calf traits recorded within $12 \mathrm{~h}$ after birth included birth weight, head and foot circumferences, width of shoulders and hips, and depth of chest. Pelvic measurements of the heifer were also obtained at $12 \mathrm{~h}$ postpartum.

The external width and depth measurements of the calf were obtained using an adapted aluminum ruler as an outside caliper. The circumference measurements were obtained with a measuring tape. Circumference of the head was measured by placing the measuring tape over the calf's poll and under the jaw bone giving the largest circumference. The foot circumference was determined by placing the measuring tape around the coronary band of the left front foot. With the calf standing, the width of shoulders was measured between the left and right lateral tuberosity of humerus. The width of hips was measured between the left and right trochanter major. The depth of chest was the distance between the crops (top of the scapula) and the chest floor (sternum). 
Table 1. Least-squares means for dam size traits by calving difficulty score

\begin{tabular}{|c|c|c|c|c|c|}
\hline \multirow[b]{2}{*}{ Trait } & \multicolumn{5}{|c|}{ Calving difficulty score ${ }^{b}$} \\
\hline & 1 & 2 & 3 & 4 & 5 \\
\hline No. dams & 197 & 25 & 104 & 33 & 30 \\
\hline \multicolumn{6}{|l|}{ Body weights, kg } \\
\hline Birth & $40.1^{d}$ & $41.0^{\text {def }}$ & $40.8^{\mathrm{de}}$ & $42.4^{\mathrm{ef}}$ & $43.0^{f}$ \\
\hline $12 \mathrm{mo}$ & $296^{d}$ & $304^{\text {de }}$ & $297^{\text {de }}$ & $306^{\mathrm{e}}$ & $302^{\mathrm{de}}$ \\
\hline $22 \mathrm{mo}$ & $435^{d}$ & $454^{e}$ & $440^{\text {de }}$ & $451^{\mathrm{e}}$ & $445^{\text {de }}$ \\
\hline \multicolumn{6}{|l|}{ Condition scores ${ }^{c}$} \\
\hline $12 \mathrm{mo}$ & 5.2 & 5.2 & 5.2 & 5.3 & 5.2 \\
\hline $22 \mathrm{mo}$ & 5.1 & 5.1 & 5.1 & 5.2 & 5.2 \\
\hline \multicolumn{6}{|l|}{ Hip height, $\mathrm{cm}$} \\
\hline $12 \mathrm{mo}$ & $118.0^{\mathrm{d}}$ & $119.3^{\text {def }}$ & $118.3^{\text {de }}$ & $119.8^{\mathrm{fg}}$ & $118.5^{\text {deg }}$ \\
\hline $22 \mathrm{mo}$ & 125.0 & 125.8 & 124.8 & 125.5 & 125.8 \\
\hline \multicolumn{6}{|l|}{ Pelvic area, $\mathrm{cm}^{2}$} \\
\hline $12 \mathrm{mo}$ & $171.8^{\mathrm{d}}$ & $174.9^{d}$ & $170.4^{d}$ & $173.7^{d}$ & $165.3^{e}$ \\
\hline $22 \mathrm{mo}$ & $245.2^{d}$ & $247.0^{d}$ & $244.3^{d}$ & $245.4^{d}$ & $235.4^{e}$ \\
\hline $25 \mathrm{mo}$ & $268.6^{d}$ & $269.0^{\text {de }}$ & $267.0^{\text {de }}$ & $266.4^{\text {de }}$ & $260.7^{e}$ \\
\hline
\end{tabular}

a Values pooled over $3 \mathrm{yr}$, with year and sire effects removed.

bScoring system 1 to 5; 1 = hand pull, $3=$ mechanical pull, and $5=$ Caesarean section.

'Scoring system of 1 to $9 ; 1=$ emaciated, $5=$ moderate, and $9=$ obese.

defgWithin a row, means with unlike superscripts differ $(P<.05)$.

Postpartum reproductive traits of the young cows included estrous cycling before the breeding season, pregnant during breeding season, and day of conception. Estrous cyclicity was determined by rectal palpation of the ovaries for corpora lutea, and blood samples were collected via jugular vein twice (May 5 and 15) to determine progesterone concentration on all cows. Samples were chilled for $24 \mathrm{~h}$ and centrifuged, and the serum was decanted and frozen until analyzed. Serum progesterone was quantified using RIA (Anthony et al., 1981) to determine luteal function. The assay had a CV of $3.2 \%$. A minimum progesterone concentration of $1.5 \mathrm{ng} / \mathrm{mL}$ was used to determine estrous cyclicity.

The 2-yr-old cows were exposed to MARC II bulls in multiple sire groups for a 75-d breeding season beginning May 19 at GSL each year. Breeding dates were recorded with the aid of chin-ball markers on bulls. Two pregnancy examinations were conducted via rectal palpation at 30-d intervals for fetal aging. Day of conception was determined by breeding dates and verified by fetal aging. In cases of disagreement between breeding date and fetal age, day of conception was adjusted according to calving date.

Growth traits measured at weaning on September 5 included cow weight and body condition score and calf weaning weights. After weaning, calves were placed in a feedlot and fed a growing-finishing diet until slaughtered the following May. The diet consisted of corn silage, ground alfalfa hay, dry rolled corn, and a $32 \%$ CP supplement. Calf average daily gain was obtained from weaning to slaughter.

Weather data were also collected over the 3-yr study. Data were collected at GSL for the months of October, N ovember, and December, and data for the months of J anuary, February, and March were collected at WCREC. Data included daily high and low temperatures and wind speed. Mean monthly air temperatures were calculated using daily high and low temperatures. Mean monthly wind chills were calculated using daily low temperatures and wind speeds.

Data were analyzed by analysis of variance for a randomized design with main effects of year and sire (SAS, 1992). Calf birth weight and sex were also used in the model as covariates for calf shape measurement analyses. For presentation purposes, variables were also fitted to a model with the effect of CDS to derive least-squares means by CDS classes. Residual correlations of dependent variables were determined with main effects of year and sire removed. Linear regression analyses were conducted on relationships between parturition traction pressure and heifer size traits, calf birth weight, and various combinations of variables. Pregnancy rate and percent calving difficulty were analyzed with Chi-square procedures (Steel and Torrie, 1980). Significant year effects were found and then removed to determine causes of dystocia pooled over years. No year $\times$ sire interactions were found, so that term was deleted from the model. Weather data were analyzed by least-squares analyses by winter period.

\section{Results and Discussion}

\section{Dam Size Traits}

Dam Weight. Heifer weights and measurements at various ages by CDS are reported in Table 1 with sire and year effects removed. Significant differences were found between CDS 1 and 4 and 5 for dam birth 
weight ( 40.1 vs 42.4 , and $43.0 \mathrm{~kg}$, respectively). Heifers that were heavy at birth experienced more calving difficulty as 2-yr-olds because they had heavier birth weight calves, which was probably due to genetics.

Heifer weights at 12 and 22 mo of age did not significantly affect the degree of calving difficulty. J ohnson et al. (1988) showed that prebreeding and precalving heifer weights were not correlated with CDS. Our results showed that selecting the heaviest heifers as yearlings did not reduce the incidence of dystocia at calving. Fagg et al. (1975), Short et al. (1979), and Morrison et al. (1985) reported that precalving cow weight was a significant factor influencing dystocia.

Condition Score. There were no differences in heifer body condition at 12 and 22 mo of age among CDS. These results are in agreement with Spitzer et al. (1995), who found that heifers calving in body condition scores of 4, 5, or 6 had no significant differences in dystocia.

Hip Height. In general, no significant differences were found in hip height at 12 or 22 mo of age among CDS. Cadle and Ruttle (1976) reported less dystocia for larger-framed heifers.

Pelvic Area. Heifer pelvic area at 12 and 22 mo of age significantly affected CDS 5; however, no other differences among CDS were found. Heifers requiring Caesarean section (CDS 5) had smaller pelvic area measurements at 12 and 22 mo of age than heifers in all other CDS groups. Results indicate that yearling pelvic measurements would be useful in detecting heifers requiring Caesarean sections. This agrees with Rice and Wiltbank (1972) and Deutscher et al. (1978), who reported that heifers with the smallest pelvic areas experienced significantly more dystocia. Gaines et al. (1993) reported that pelvic area measurements at any time other than calving were not associated with dystocia. Heifer pelvic areas at calving (25 mo) showed the same significant differences between CDS as at $12 \mathrm{mo}$ and $22 \mathrm{mo}$ in the present study. This indicates precise measurements and high correlations (.75) between times of measurements.

\section{Calf Measurements}

Traction Pressure. As expected, the traction pressure significantly increased as CDS increased (Table 2 ). Kilograms of pressure required for each CDS were 47, 208, 305, and 386 for scores 2, 3, 4, and 5, respectively. This pressure directly measured the severity of calving difficulty. This will be discussed further in the regression analyses section.

Birth Weight. Calf birth weight significantly increased $(P<.05)$ as CDS increased and was the most important factor of those evaluated for determining CDS. Calf birth weight has been reported to be the most important factor affecting the incidence and severity of dystocia (Meijering, 1984; Morrison et al., 1985; J ohnson et al., 1988).

External Measurements. Table 2 shows calf external measurements by CDS with effects of year, sire, sex of calf, and calf birth weight removed. Significant differences were found for head and foot circumferences, width of shoulders, and depth of chest among CDS. Score 5 had significantly larger head circumferences compared with CDS 2. Foot circumference and width of shoulders were significantly larger for CDS 5 than for CDS 1. Meijering (1984) and Morrison et al. (1985) found no differences in effects of calf body measures on dystocia independent of birth weight. No differences were found for width of hips for CDS. The results for width of hips may be due to the procedure used in handling calves during parturition. During assisted deliveries, calves were rotated to reduce the possibility of hip lock and avoid causing further stress to the calf and heifer. Calf depth of chest results were

Table 2. Least-squares means for calf measurements by calving difficulty score

\begin{tabular}{|c|c|c|c|c|c|c|}
\hline \multirow[b]{2}{*}{ Trait } & \multicolumn{6}{|c|}{ Calving difficulty score ${ }^{b}$} \\
\hline & 1 & 2 & 3 & 4 & 5 & SE \\
\hline No. calves & 197 & 25 & 104 & 33 & 30 & \\
\hline Traction pressure, kg & - & $47.0^{\mathrm{e}}$ & $207.8^{f}$ & $305.0^{\mathrm{g}}$ & $386.4^{\mathrm{h}}$ & \\
\hline Birth weight, $\mathrm{kg}$ & $32.5^{\mathrm{e}}$ & $34.5^{f}$ & $35.9^{9}$ & $37.5^{\mathrm{h}}$ & $39.8^{\mathrm{i}}$ & \\
\hline Head circumference, ${ }^{C} \mathrm{~cm}$ & $45.73^{\mathrm{ef}}$ & $45.40^{e}$ & $45.59^{\mathrm{ef}}$ & $45.64^{\mathrm{ef}}$ & $46.05^{f}$ & .18 \\
\hline Foot circumference, ${ }^{\mathrm{C}} \mathrm{cm}$ & $17.11^{\mathrm{e}}$ & $17.29^{\mathrm{fg}}$ & $17.13^{\mathrm{eg}}$ & $17.09^{\mathrm{eg}}$ & $17.36^{f}$ & .06 \\
\hline Width of shoulders, ${ }^{\mathrm{C}} \mathrm{cm}$ & $20.47^{e}$ & $20.62^{e f}$ & $20.67^{\text {ef }}$ & $20.63^{e f}$ & $20.95^{f}$ & .15 \\
\hline Width of hips, ${ }^{\mathrm{C}} \mathrm{cm}$ & 22.45 & 22.18 & 22.16 & 22.19 & 22.22 & .19 \\
\hline Depth of chest, ${ }^{c} \mathrm{~cm}$ & $29.21^{\text {ef }}$ & $29.60^{e}$ & $29.12^{\mathrm{fg}}$ & $29.25^{\mathrm{eg}}$ & $29.22^{\mathrm{eg}}$ & .15 \\
\hline Vigor score ${ }^{\mathrm{d}}$ & $2.8^{\mathrm{e}}$ & $3.2^{f g}$ & $3.1^{f}$ & $3.6^{9}$ & $2.9^{e f}$ & \\
\hline
\end{tabular}

a Values pooled over $3 \mathrm{yr}$, with year and sire effects removed.

bScoring system 1 to 5; $1=$ no assistance, $3=$ mechanical pull, and $5=$ Caesarean section.

'Calf values had sex of calf and birth weight removed.

dScoring system 1 to $5 ; 1=$ nursed unassisted within $30 \mathrm{~min}, 3=$ nursed unassisted within 75 min, and $5=$ dead at birth.

efghi Within a row, means with unlike superscripts differ $(P<.05)$. 
Table 3. Least-squares means for dam and calf measurements by sire ${ }^{a}$

\begin{tabular}{|c|c|c|c|c|c|}
\hline \multirow[b]{2}{*}{ Trait } & \multicolumn{2}{|c|}{ Low sire } & \multicolumn{3}{|c|}{ High sire ${ }^{b}$} \\
\hline & 1 & 2 & 3 & 4 & SE \\
\hline No. dams & 139 & 137 & 137 & 136 & \\
\hline 12-mo dam weight, kg & 296.7 & 296.7 & 298.2 & 297.8 & \\
\hline 12-mo dam pelvic area, $\mathrm{cm}^{2}$ & 170.6 & 170.2 & 170.5 & 170.6 & \\
\hline No. calves & 106 & 93 & 94 & 96 & \\
\hline Calf birth weight, kg & $32.9^{f}$ & $33.1^{f}$ & $35.8^{\mathrm{g}}$ & $36.4^{\mathrm{g}}$ & \\
\hline Head circumference, ${ }^{\mathrm{C}} \mathrm{cm}$ & $45.30^{f}$ & $45.68^{h}$ & $46.04^{9}$ & $45.74^{\mathrm{gh}}$ & .12 \\
\hline Foot circumference, ${ }^{\mathrm{C}} \mathrm{cm}$ & $16.92^{f}$ & $17.05^{\mathrm{h}}$ & $17.50^{9}$ & $17.13^{\mathrm{h}}$ & .05 \\
\hline Width of shoulders, ${ }^{\mathrm{C}} \mathrm{cm}$ & 20.67 & 20.58 & 20.49 & 20.61 & .11 \\
\hline Width of hips, ${ }^{c} \mathrm{~cm}$ & 22.38 & 22.31 & 22.24 & 22.31 & .13 \\
\hline Depth of chest,c cm & 29.14 & 29.23 & 29.31 & 29.16 & .10 \\
\hline Traction pressure, $\mathrm{kg}$ & $111.9^{f}$ & $104.7^{f}$ & $164.8^{9}$ & $135.3^{\text {fg }}$ & \\
\hline Calving difficulty, $\%$ & $41^{\mathrm{fh}}$ & $33^{f}$ & $52^{9}$ & $46^{\mathrm{gh}}$ & \\
\hline Calving difficulty score & $2.0^{\mathrm{fh}}$ & $1.9^{f}$ & $2.5^{9}$ & $2.2^{\mathrm{gh}}$ & \\
\hline Caesarean section, \% & $3^{f}$ & $5^{f}$ & $16^{9}$ & $7^{f}$ & \\
\hline Vigor score $\mathrm{e}^{\mathrm{e}}$ & $2.7^{f}$ & $3.0^{\mathrm{fh}}$ & $3.2^{g h}$ & $3.3^{9}$ & \\
\hline
\end{tabular}

avalues pooled over $3 \mathrm{yr}$, with year effects removed.

bSire birth weight EPD: $1=-.95,2=-.82,3=+2.9$, and $4=+2.7 \mathrm{~kg}$.

Values pooled over $3 \mathrm{yr}$ with year and calf birth weight removed.

${ }^{\mathrm{d} C}$ Calving difficulty scores 3 to 5 .

eScoring system 1 to 5; 1 =nursed unassisted within $30 \mathrm{~min}, 3$ =nursed unassisted within $75 \mathrm{~min}$, and 5 = dead at birth.

fghWithin a row, means with unlike superscripts differ $(P<.05)$.

inconsistent across CDS. Results for width of hips are in agreement with previous research indicating no differences in calf measurements independent of calf birth weight. Laster (1974) showed a correlation of .75 between five calf shape measurements and calf birth weight, but calf shape measurements, independent of birth weight, had no effect on dystocia. Nugent et al. (1991) found calf shape measurements, independent of calf birth weight, had no significant effects on dystocia. Head circumference and width of shoulder measurements seem to be the best indicators of degree of dystocia for calf measurements in our data set.

Calf Vigor. Calf vigor score increased $(P<.05)$ as CDS increased up to CDS 4, with less vigorous calves coming from the more difficult births. Score 5 was not different from CDS 1, indicating that calves born through Caesarean section did not experience any more stress and were as vigorous as calves born unassisted.

\section{Sire Effects}

There were no differences for dam yearling weight and pelvic area among the sires due to the heifer allotment procedure (Table 3).

Calf Measurements. Calf birth weight was significantly different between sire groups, 33 vs $36.1 \mathrm{~kg}$, low vs high, respectively. The difference in birth weight EPD between the two sire groups was $3.6 \mathrm{~kg}$, indicating that sire birth weight EPD was a good predictor of differences in average calf birth weight. However, the range of birth weights within a sire were
27 to $45 \mathrm{~kg}$. Predictability of birth weight for a single calf is low (Price and Wiltbank, 1978; Short et al., 1979; Morrison et al., 1985), causing a wide range of birth weights within sires and causing more dystocia than expected.

Head and foot circumferences were significantly different between the low and high EPD sires, even when adjusted for calf birth weight. Nugent et al. (1991) showed that sire birth weight EPD was positively correlated $(P<.05)$ with all calf measurements, but only with head and cannon circumferences after adjustment for phenotypic birth weight. They also showed sire differences for Angus-sired calves. However, after adjustment for birth weight, only cannon bone circumference differed $(P<.05)$ among half-sib groups.

Differences were found $(P<.05)$ between the two low-birth-weight EPD sires for head circumference (45.3 vs $45.7 \mathrm{~cm}$ ) and foot circumference (16.9 vs 17.0 $\mathrm{cm})$, respectively. There were significant differences between the two high EPD sires for calves' foot circumference. However, sires 2 and 4 were not different for calves' head and foot circumferences. These results suggest there were differences between sires within birth weight EPD groups, independent of calf birth weight. Also, there were similarities between sires of each birth weight EPD group. No significant differences were found for width of shoulders, width of hips, or depth of chest among sires.

Percent calving difficulty was lower for heifers bred to the low EPD sires. However, sire 1 (birth weight EPD -.95) was not different from sire 4 (birth weight EPD +2.7), even though they were significantly 
Table 4. Least-squares means for dam reproductive traits after calving by calving difficulty score

\begin{tabular}{|c|c|c|c|c|c|}
\hline \multirow[b]{2}{*}{ Trait } & \multicolumn{5}{|c|}{ Calving difficulty score ${ }^{b}$} \\
\hline & 1 & 2 & 3 & 4 & 5 \\
\hline No. 2-yr-old dams & 195 & 25 & 107 & 29 & 30 \\
\hline Estrous cycling, \% & 43.8 & 41.7 & 37.1 & 40.0 & 25.0 \\
\hline Conception date & J une $13^{c}$ & J une $16^{\text {cd }}$ & J une $18^{d}$ & J une $24^{d}$ & J une $15^{c c}$ \\
\hline Pregnancy $75 \mathrm{~d}, \%$ & 89.8 & 84.0 & 92.5 & 89.7 & 80.0 \\
\hline No. 3-yr-old dams & 159 & 20 & 94 & 20 & 21 \\
\hline Second calf birth weight, $\mathrm{kg}$ & $38.7^{c}$ & $39.5^{\mathrm{cd}}$ & $39.6^{\mathrm{cd}}$ & $41.7^{d}$ & $39.6^{\mathrm{cd}}$ \\
\hline Second calving difficulty, \% & $5.7^{c}$ & $10.0^{\text {cd }}$ & $8.5^{\mathrm{c}}$ & $30.0^{d}$ & $9.5^{\mathrm{cd}}$ \\
\hline
\end{tabular}

aValues pooled over $3 \mathrm{yr}$, with year and sire effects removed.

bScoring system 1 to 5; $1=$ no assistance, $3=$ mechanical pull, and $5=$ Caesarean section.

cdWithin a row, means with unlike superscripts differ $(P<.05)$.

different for birth weight. There were significant differences between the low EPD sires compared with the high EPD sire 3 for the percentage of Caesareans. A significant difference was found between the two high sires: $16 \%$ for sire 3 and $7 \%$ for sire 4 . This difference cannot be explained by the difference in birth weight, which was similar. Therefore, the difference may be due to more bone per unit of calf birth weight for sire 3, thus causing more dystocia. Table 3 shows that sire 3 had a larger foot circumference (larger bone) at a constant birth weight compared with sire 4.

There were significant differences in calf vigor score among sires. Calves by sire 1 were significantly different from those by sire 4 . These two sires are of interest because they were significantly different for calf birth weight but not CDS. This may indicate that calf birth weight may be related to calf vigor; heavier calves may be less vigorous and slower to nurse.

\section{Reproductive Traits}

No differences were found in percentage of heifers having estrous cycles before the breeding season by CDS. Significant differences were found in conception date between CDS 1 compared with 3 and 4 (Table 4). There was a trend $(P<.20)$ as CDS increased to 4 , conception date increased from J une 13 to J une 24 . Score 5 was not significantly different from the other CDS, but these heifers had the second earliest conception date. These data indicate that even though these heifers required Caesarean sections, they experienced less stress during and following parturition. There were no significant differences for percentages of heifers pregnant among CDS. These results are in disagreement with those of Laster et al. (1973), who showed that dystocia resulted in lower conception rates.

No significant differences were observed for second calf birth weight by CDS; however, the second calf birth weights were heavier than those of the first calf. There were significant differences in percent calving difficulty for 3-yr-old cows. The heifers in CDS 1 as 2-yr-olds experienced $5.7 \%$ calving difficulty as 3-yr-olds compared with $30.0 \%$ of the heifers in CDS 4. Heifers in CDS 5 (Caesarean section) experienced only $9.5 \%$ calving difficulty as 3 -yr-old cows. These results show that heifers experiencing dystocia as 2-yr-olds will have considerably less calving difficulty as 3-yr-olds. Laster et al. (1973) reported that age of dam was a major source of variation of calving difficulty. Bellows et al. (1982) showed that dystocia scores for heifers exceeded those for cows $(P<.01)$, even though calves from cows were $4.0 \mathrm{~kg}$ heavier $(P<$ $.01)$ than calves from heifers. This difference was due to larger precalving pelvic dimensions for cows than heifers, resulting in less disproportion between size of dam and calf.

\section{Regression Analyses}

A comparison of the traction pressure system with the standard CDS system using a selected data set is shown in Table 5. All unassisted births and Caesarean sections were deleted from the analyses. The traction pressure system was able to detect only a slightly larger amount of variation affecting dystocia than the standard five-point scoring system. The $\mathrm{R}^{2}$ values for the traction pressure data were approximately $2 \%$ higher for the dam traits and approximately 3\% higher for the calf traits than the CDS data. The CV were similar between the two systems. Therefore, the standard five-point CDS system seems adequate for describing the degree of dystocia, and measuring traction pressure may not improve characterizing dystocia over the five-point system. Therefore, the data in this study were evaluated with the CDS classes.

Stepwise regression analyses were performed on individual calf measurements and the 22 -mo pelvic area measurement in the model for traction pressures and CDS. In both scoring systems, calf birth weight accounted for the most variation (33.1 and 33.4\% of pressure and CDS, respectively). The next variables brought into the analyses were 22-mo pelvic area, width of hips, and width of shoulders for a total $R^{2}$ of $43 \%$. When an analysis was performed using only traction pressures between 47 and $380 \mathrm{~kg}$, calf birth 
Table 5. Comparison of models to explain variation

in calving difficulty score and traction pressure ${ }^{\mathrm{a}}$

\begin{tabular}{llllll}
\hline \hline & \multicolumn{2}{c}{ Calving difficulty score } & & \multicolumn{2}{c}{ Traction pressure } \\
\cline { 2 - 3 } \cline { 6 - 6 } Trait & $\mathrm{R}^{2}$ & $\mathrm{CV}$ & & $\mathrm{R}^{2}$ & $\mathrm{CV}$ \\
\hline Dam & & & & & \\
22-mo pelvic area & .043 & 20.0 & & .064 & 19.7 \\
Dam birth weight & .045 & 19.9 & & .062 & 19.7 \\
22-mo weight & .043 & 20.0 & & .064 & 19.7 \\
Calf & & & & & \\
$\quad$ Birth weight & .111 & 19.2 & & .160 & 18.6 \\
Head circumference & .122 & 18.8 & & .156 & 18.6 \\
Foot circumference & .080 & 19.2 & & .106 & 19.1 \\
\hline
\end{tabular}

a $V$ alues pooled over $3 \mathrm{yr}$, with year and sire effects removed.

weight was the number one variable accounting for the most variation, followed by the 22-mo pelvic area, calf foot circumference, and head circumference. Regression $\mathrm{R}^{2}$ for dam pelvic areas at 12,18 , and 22 mo accounted for a low percentage of variation (8.4, 8.3 , and $8.9 \%$, respectively) in the pressure required to deliver the calf. In contrast, calf birth weight accounted for $36.5 \%$ of the variation in traction pressure, indicating that birth weight is the primary single factor affecting dystocia in 2-yr-old heifers. These results are in agreement with those of J ohnson et al. (1988), who showed calf birth weight accounted for $33 \%$ of the variation in calving difficulty. When these two traits were combined, the pelvic area:calf birth weight ratio in our study accounted for 35 to $38 \%$ of the variation in dystocia. These results support the concept that dystocia is caused by a disproportion between calf size (birth weight) and the pelvic opening.

\section{Correlation Analyses}

Yearling pelvic area (.78) and 18-mo pelvic area (.83) were significantly correlated with precalving pelvic area, indicating that yearling and 18-mo pelvic areas might be used as indicators of precalving pelvic area. J ohnson et al. (1988) also found that prebreeding and precalving areas were highly correlated.
Pelvic area growth is continuous from yearling to after calving, and measurements can be obtained at any time during this period to determine relative differences among heifers. Precalving dam weight (22-mo) was positively correlated (.45) with 22-mo pelvic area.

Calf birth weight was found to be highly correlated $(P<.05)$ with head circumference $(.82)$, foot circumference (.79), width of shoulders (.77), width of hips (.73), and depth of chest (.73), indicating that larger birth weight calves have larger external measure ments. Calf foot circumference accounted for $62 \%$ of the variation in birth weight, indicating that foot circumference may be a good indicator of birth weight. Calf birth weight was highly correlated (.57) with CDS. Calf head circumference, foot circumference, and width of shoulders were highly correlated with CDS, $.51, .52$, and .52 , respectively.

\section{Calf Growth}

Table 6 shows the weights of calves from weaning to slaughter by CDS. Calves delivered by Caesarean section were significantly lighter at weaning than calves from CDS 1, 2, and 3. No obvious explanation is known because these calves were the heaviest at birth. We theorize that the Caesarean surgery may have negatively affected milk production of the heifers, which slowed growth of the calves. However, these

Table 6. Weaning and postweaning growth traits of calves by calving difficulty score ${ }^{a}$

\begin{tabular}{|c|c|c|c|c|c|}
\hline \multirow[b]{2}{*}{ Trait } & \multicolumn{5}{|c|}{ Calving difficulty score } \\
\hline & 1 & 2 & 3 & 4 & 5 \\
\hline Weaning weight, ${ }^{b} \mathrm{~kg}$ & $218^{d}$ & $218^{d}$ & $218^{d}$ & $214^{\text {de }}$ & $209^{e}$ \\
\hline Slaughter weight, ${ }^{c} \mathrm{~kg}$ & $513^{d}$ & $541^{e}$ & $532^{\mathrm{e}}$ & $535^{e}$ & $538^{e}$ \\
\hline$A D G,{ }^{C} \mathrm{~kg} / \mathrm{d}$ & $1.2^{\mathrm{d}}$ & $1.3^{\mathrm{e}}$ & $1.3^{\mathrm{e}}$ & $1.3^{\mathrm{e}}$ & $1.4^{\mathrm{e}}$ \\
\hline
\end{tabular}


Table 7. Winter temperatures, calf birth weights, and percent calving difficulty over three winters

\begin{tabular}{lcccc}
\hline \hline & \multicolumn{4}{c}{ Winter } \\
\cline { 2 - 5 } Trait & $1992 / 1993$ & $1993 / 1994$ & $1994 / 1995$ & Year difference $^{\mathrm{a}}$ \\
\hline Mean air temperatures, ${ }^{\circ}{ }^{\circ} \mathrm{C}$ & $-6.7^{\mathrm{c}}$ & $-3.3^{\mathrm{d}}$ & $-.6^{\mathrm{d}}$ & +6.1 \\
Mean wind chill, ${ }^{\circ} \mathrm{C}$ & $-11.1^{\mathrm{c}}$ & $-7.8^{\mathrm{c}}$ & $-5^{\mathrm{d}}$ & +6.1 \\
Calf birth weight, $\mathrm{kg}$ & $37.3^{\mathrm{c}}$ & $34.5^{\mathrm{d}}$ & $32.7^{\mathrm{d}}$ & -4.6 \\
Calving difficulty, \% & $58^{\mathrm{c}}$ & $47^{\mathrm{c}}$ & $35^{\mathrm{d}}$ & -23 \\
\hline
\end{tabular}

aDifferences between first and last year.

bMean air temperatures and wind chill are for the months of December, J anuary, and February.

cdWithin a row, means with unlike superscripts differ $(P<.10)$.

calves showed compensatory gain in the feedlot and had similar slaughter weights. The only calves gaining significantly slower in the feedlot were the CDS 1 group. These calves were the smallest at birth and may have had less genetic growth potential.

Weather Effects

Air and wind chill temperatures increased over the 3-yr study (Table 7). The greatest differences between years were found during the months of December, $\mathrm{J}$ anuary, and February. The mean air temperature was significantly warmer $\left(6.1^{\circ} \mathrm{C}\right)$ for the winter of 1994-1995 than the 1992-1993 winter. The winter of 1994-1995 was noticeably warmer than the winter of 1992-1993, with an overall higher wind chill temperature of $6.1^{\circ} \mathrm{C}$.

Spring calf birth weights were significantly lower $(4.6 \mathrm{~kg})$ in 1995 than in 1993. These data lead one to hypothesize that calf birth weights were lower after a winter with warmer air temperatures and less severe wind chills. During cold winters, blood flow to the uterus may be increased, resulting in more nutrients available to the fetus, causing increased birth weights. Blood flow is the primary determinant of nutrient uptake by the uterus (Ferrell, 1991). Heifers consumed more hay during colder temperatures, which would increase nutrients to the fetus; however, we estimate that this increase would change calf birth weight by only $1 \mathrm{~kg}$. Also, longer gestations can increase calf birth weight; however, the average calf gestation length was not different between years. Calving difficulty percentage also decreased by $23 \%$ from 1993 to 1995 (58\% to 35\%, respectively).

It seems from these data that the months of December, J anuary, and February, which had the coldest temperatures, had the greatest effect on fetal growth. These months coincided with the last trimester of growth of the fetus. Approximately $90 \%$ of the birth weight is achieved during the last $40 \%$ of gestation in bovine (Ferrell et al., 1976). These results suggest that greater calf birth weight and calving difficulty may be expected in the spring following severe winter temperatures.

\section{Implications}

Causes of dystocia are complex because many factors are interrelated, and methods to reduce dystocia are complicated. Selecting sires with low birth weight expected progeny differences helps produce calves with reduced bone size and birth weights. Extreme calving difficulty can be reduced by culling yearling heifers with heavy birth weights and small pelvic measurements. It was found that calf head circumference and width of shoulder measurements affected dystocia, independent of birth weight. Producers can reduce dystocia by using improved management practices.

\section{Literature Cited}

Anderson, K. J ., J . Brinks, D. LeFever, and K. Odde. 1993. The factors associated with dystocia in cattle: A strategy for minimizing calving difficulty. Vet. Med. (August):764-781.

Anthony, R. V., R. J . Kittok, E. F. Ellington, and M. K. Nielsen. 1981. Effects of zeronal on growth and ease of calf delivery in beef heifers. J. Anim. Sci. 53:1325-1332.

Bellows, R. A., R. E. Short, and G. V. Richardson. 1982. Effects of sire, age of dam and gestation feed level on dystocia and postpartum reproduction. J. Anim. Sci. 55:18.

Brinks, J. S., J . E. Olson, and E. J . Carroll. 1973. Calving difficulty and its association with subsequent productivity in Herefords. J. Anim. Sci. 36:11.

Cadle, J. M., J r., and J. L. Ruttle. 1976. Dystocia in range beef heifers. J. Anim. Sci. 43:227 (Abstr.).

Deutscher, G. H. 1978. Factors influencing dystocia and pelvic area in beef heifers. J. Anim. Sci.47(Suppl. 1):8 (Abstr.).

Deutscher, G. H. 1989. Pelvic measurements of heifers and bulls for reducing dystocia. Beef Improvement Federation Conf., Nashville, TN.

Fagg, B. W., W. L. Singleton, L. A. Nelson, and D. A. Huber. 1975. Dystocia in crossbred heifers. J. Anim. Sci. 41:266(Abstr.).

Ferrell, C. L. 1991. Maternal and fetal influences on uterine and conceptus development in the cow: II. Blood flow and nutrient flux. J. Anim. Sci. 69:1954.

Ferrell, C. L., W. N. Garrett, and N. Hinman. 1976. Growth, de velopment and composition of the udder and gravid uterus of beef heifers during pregnancy. J . Anim. Sci. 42:1477.

Gaines, J. D., D. Peschel, R. G. Kauffman, D. M. Schaefer, G. Badtram, J . Kumi-Diaka, M. K. Clayton, and G. Milliken. 1993. Pelvic growth, calf birth weight, and dystocia in Holstein $\times$ Hereford heifers. Theriogenology 40:33.

J ohnson, S. K., G. H. Deutscher, and A. Parkhurst. 1988. Relationships of pelvic structure, body measurements, pelvic area and calving difficulty. J. Anim. Sci. 66:1081. 
Laster, D. B. 1974. Factors affecting pelvic size and dystocia in beef cattle. J . Anim. Sci. 38:496.

Laster, D. B., H. A. Glimp, L. V. Cundiff, and K. E. Gregory. 1973. Factors affecting dystocia and the effects of dystocia on subsequent reproduction in beef cattle. J. Anim. Sci. 36:695.

Meijering, A. 1984. Dystocia and stillbirth in cattle-a review of causes, relations and implications. Livest. Prod. Sci. 11:143.

Morrison, D. G., P. E. Humes, N. K. Keith, and R. A. Godke. 1985. Discriminant analysis for predicting dystocia in beef cattle. I. Comparison with regression analysis. J. Anim. Sci. 60:608.

Nugent, R. A. III, D. R. Notter, and W. E. Beal. 1991. Body measurements of newborn calves and relationship of calf shape to sire breeding values for birth weight and calving ease. J. Anim. Sci. 69:2413.

Patterson, D. J ., R. A. Bellows, P. J . Burfening, R. E. Short, and J . B. Carr. 1979. Incidence and causes of neonatal and postnatal mortality in range cattle. J. Anim. Sci. 49(Suppl. 1):325 (Abstr.).

Price, T. D., and J . N. Wiltbank. 1978. Dystocia in cattle: A review and implications. Theriogenology 9:195.
Rice, L. E., and J . N. Wiltbank. 1972. Factors affecting dystocia in beef heifers. J . Am. Vet. Med. Assoc. 161:1348.

SAS. 1992. SAS User's Guide: Statistics (Version 6 Ed.). SAS Inst. Inc., Cary, NC.

Short, R. E., R. A. Bellows, R. B. Staigmiller, and J . B. Carr. 1979. Multiple linear and nonlinear regression analysis of factors causing calving difficulty. Theriogenology 12:121.

Smith, G. M., D. B. Laster, and K. E. Gregory. 1976. Characterization of biological types of cattle I. Dystocia and preweaning growth. J. Anim. Sci. 43:27.

Spitzer, J . C., D. G. Morrison, R. P. Wettemann, and L. C. Faulkner. 1995. Reproductive responses and calf birth and weaning weights as affected by body condition at parturition and postpartum weight gain in primiparous beef cows. J . Anim. Sci. 73: 1251.

Steel, R.G.D., and J . H. Torrie. 1980. Principles and Procedures of Statistics: A Biometrical Approach (2nd Ed.). McGraw-Hill Publishing, New York.

Wiltbank, J. N., E. J. Warwick, E. H. Vernon, and B. M. Priode. 1961. Factors affecting net calf crop in beef cattle. J . Anim. Sci. 20:409. 